\title{
Vol. 1 No. 1, April 2019
}

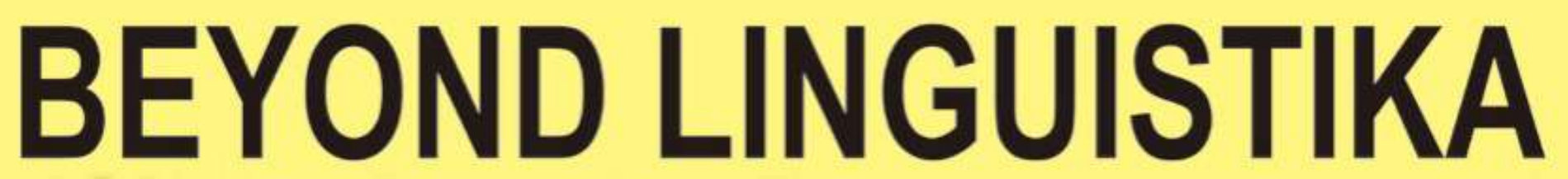

(Journal of Linguistics and Language Education)

\section{FKIP}

English Department

Jl. Zainal Abidin Pagar Alam No.26, Labuhan Ratu,

Kedaton, Kota Bandar Lampung, Lampung 35142 
DEWAN REDAKSI

Beyond Linguistika

Penanggung Jawab

Rektor Universitas Bandar Lampung

Ketua Penyunting

Yanuarius Yanu Dharmawan, S.S., M.Hum.

Wakil Ketua Penyunting

Dameria Magdalena S., S.Pd., M.Hum.

\author{
Penyunting Pelaksana: \\ Drs. Harpain, M.A.T., M.M. \\ Yanuar Dwi Prastyo, S.Pd.I., M.A., Ph.D. \\ Helta Anggia, S.Pd., M.A. \\ Dameria Magdalena S., S.Pd., M.Hum. \\ Wayan Karang Yana, S.Pd., M.A. \\ Yanuarius Yanu Dharmawan, S.S., M.Hum.
}

Penerbit:

Program Studi Pendidikan Bahasa Inggris Fakultas Keguruan dan Ilmu Pendidikan Universitas Bandar Lampung
MITRA BESTARI:

Prof. Dr. Cucu Sutarsyah, M.A.

(Universitas Lampung, Indonesia)

Dr. Agus Wahyudi, M.S.

(Universitas Bandar Lampung, Indonesia)

Dr. Hery Yufrizal, M.A.

(Universitas Lampung, Indonesia)

Drs. Basturi Hasan, M.A.

(Universitas Lampung, Indonesia)

\author{
Kantor: \\ Fakultas Keguruan dan Ilmu Pendidikan \\ Kampus A Universitas Bandar Lampung \\ Gedung Rektorat Lt.3 J1. Z.A. Pagar Alam No. 26 \\ Labuhan Ratu 35142, Bandar Lampung \\ Telp. (0721) 771331, \\ e-mail: beyondlinguistika@ubl.ac.id
}

Beyond Linguistika, Jurnal Kebahasaan dan Pendidikan Bahasa, merupakan jurnal ilmiah yang menyajikan artikel orisinal tentang bahasa dan kebahasaan. Jurnal ini merupakan sarana publikasi dan ajang berbagi riset dan pengembangannya di bidang bahasa secara global. Pemuatan artikel di jurnal ini dialamatkan ke kantor editor. Informasi lengkap untuk pemuatan artikel dan petunjuk penulisan artikel tersedia di dalam setiap terbitan. Artikel yang masuk akan diproses seleksi editor. Jurnal ini terbit secara berkala sebanyak dua kali dalam setahun (April dan Oktober).

Beyond Linguistika, Journal of Linguistics and Language Education, is a scientific journal that presents original articles on Linguistics and Language education. This journal is a means of publication and a place to share research and development in the field of language globally. Loading articles in this journal is sent to the editor's office. Complete information for loading articles and instructions for writing articles is available in every issue. The incoming article will be processed by the editor selection. This journal is published regularly twice a year (April and October).

Mengutip ringkasan dan pernyataan atau mencetak ulang gambar atau tabel dari jurnal ini harus mendapat ijin langsung dari penulis. Produksi ulang dalam bentuk kumpulan cetakan ulang atau untuk kepentingan periklanan atau promosi atau publikasi ulang dalam bentuk apa pun harus seizin salah satu penulis dan mendapat lisensi dari penerbit. Jurnal ini diedarkan sebagai tukaran untuk perguruan tinggi, lembaga penelitian dan perpustakaan di dalam negeri.

Quoting summaries and statements or reprinting images or tables from this journal must get permission directly from the author. Reproduction in the form of a collection of reprints or for the purposes of advertising or promotion or re-replication in any form must be authorized by one of the authors and obtain a license from the publisher. This journal is circulated as an exchange for universities, research institutions and libraries in the country. 


\section{CONTENTS}

STUDENTS'PERCEPTIONS IN USING NARROW READING AND NARROW LISTENING IN SPEAKING CLASS AT THIRD SEMESTER OF ENGLISH DEPARTMENT UNIVERSITAS BANDAR LAMPUNG

Rizki Adelia Putri, Yanuarius Yanu Dharmawan .......................................... 4

THE CRITICAL DISCOURSE ANALYSIS ON THE FAME OF OREO WONDERFILLED ADVERTISEMENT

Alfriani Ndandara, Frederika Mei Anggraeni .14

SPEECH ACTS IN LANGUAGE COMMONLY USED BY PADDY CAB DRIVERS IN PRAWIROTAMAN AREA YOGYAKARTA

Anita Wijayanti, Ria Saputra

THE INFLUENCE OF THE ENVIRONMENT ON MISPRONUNCIATION OF ENGLISH COMMON WORDS IN INDONESIA (CASE STUDY)

Yanuarius Yanu Dharmawan, Immaniar, Layalia Faza

DEPICTING STEREOTYPICAL REPRESENTATION OF FEMALE CHARACTER IN ANTON CHEKHOV'S LADY WITH THE DOG

Athriyana S. Pattiwael

RAISING STUDENT'S EXECUTIVE COGNITIVE FUNCTION THROUGH STUDENTS-CENTERED LEARNING APPROACH IN TEACHING CREATIVE WRITING

Emanuella Christine Natalia Mau. .56 


\title{
THE CRITICAL DISCOURSE ANALYSIS ON THE FAME OF OREO WONDERFILLED ADVERTISEMENT"
}

\author{
Alfriani Ndandara, Frederika Mei Anggraeni \\ Sanata Dharma University, Yogyakarta. \\ Corresponding Email: Frederikamey@gmail.com
}

\begin{abstract}
Advertisement is one of functional texts which functions to commerce the audience about a product the company sells. A text in the advertisement is considered to contribute people's intention. This paper conducts a critical analysis on the fame of a product which becomes remarkable since it rises until now, Oreo. Fairclough's three dimensional frameworks, Gee's seven building tasks, and Halliday's functional grammar are employed to do the research. Therefore, this paper discusses the linguistic features, advertisement invention, semiotic aspects, and social contexts. However, the result of the research shows that, the language used in Oreo Wonderfilled advertisement has relation to power. Thus, the advertisement of Oreo does not only attract consumer but also shape the costumers' mind through the language used both its' audio or visual. The representation of symbolic power to capture the hearts and minds of consumers is by means of visual, audio, and verbal signs, which are analyzed using semiotics feature.
\end{abstract}

Keywords: advertisement, Oreo Wonderfilled, three-dimension, seven building tasks, functional grammar.

\section{INTRODUCTION}

Attracted advertisement is one of important elements in selling product. Thus, the common generic structures of advertisement such as the purpose of the advertisement, the name of a product to sell, and who is the target user of the product are needed in creating it. Since, costumers need to be convinced by the advertisement about the sell product, hence those structures need to be applied correctly and attractively, and thereby the product will get good response from costumers.

Oreo is one of the food products of Kraft Company. It is a chocolate sandwich cookie with a white creamy filling. Kraft Company as one of the companies in the world has encouraged consumers since it raise. Oreo as a chocolate cookies has maintained its' fame which can be seen from the knowledge of costumers about the original taste of Oreo cookies and the modified tastes of Oreo cookies. It has succeeded in shaping the costumers' mindset about the procedure of eating it. The best way to eat Oreo is dunking it in milk or twisting off one side and then eating the middle first, even they can combine it with cakes, milkshakes, ice creams and other additional desserts.

The Oreo advertisement is seen as a media discourse involves language and social processes. Since language carries meaning, the language used in Oreo advertisement may have relation to power. Thus, the advertisement of Oreo does not only attract costumers but also shape the costumers' mind through the language used, which is called ideology. Those phenomenon generate researchers to investigate the Oreo advertisement through the Fairclough threedimension framework and the seven main language realities (Gee's seven building task).

There are two important issues to be revealed in this study. First is the fame of Oreo advertisement in attracting the costumers, second is its' effect on costumers view point of social life. The two related issues are described in the next session. 


\section{WORKING DEFINITION OF OREO AND ITS' HISTORY}

The origin name of Oreo is unknown. However, there is some close related words root to Oreo. First, the word is derived from French word 'Or' which means gold. It can be seen from the early color package of Oreo cookie which is in gold color. Second, the word is derived from Greek word 'Oreo' which means beautiful, nice or well done. Third, the name is a combination of taking the 're' from 'cream' and placing it between the two 'o's in chocolate - making 'o-re-o'. The last, it is just named as Oreo because the word is easy to pronounce and to remember. Otherwise, there are some stereotype meanings of the word. The word 'Oreo' is referring to African American people usually act like a 'white' for dating Caucasian girls, dressing too white, talking too white, and even thinking too white. They are branded as 'Oreo' since they are 'Black on the outside, White on the inside'. Also, the word refers to 'yellow' as 'Asian' on the outside and white on the inside.

No matter how it deals with the definition of term, how it got termed, over 462 billion Oreo cookies have been sold since it was first introduced in 1912, making it the best-selling cookie product of the 20th century. Oreo has grown to take part of twentieth century culture. Oreo cookie has become the best-selling product since 1912 in U.S. In 1898, several baking companies merged to form the National Biscuit Company ( $\mathrm{NaBisCo}$ ), the maker of Oreo cookies. By 1902, NaBisCo created Barnum's Animal cookies and made them famous by selling them in a little box designed like a cage with a string attached (to hang on Christmas trees). In 1912, $\mathrm{NaBisCo}$ had a new idea for a cookie - two chocolate disks with a crème filling in between. The first Oreo cookie is looked very similar to the Oreo cookie of today, with only a slight difference in the design on the chocolate disks. The shape and design of the Oreo cookie do not change much until $\mathrm{NaBisCo}$ begin selling various versions of the cookie. In 1975, NaBisCo is released their Double Stuff Oreo. Nabisco is continuing to create variations: in 1976, Football Oreo is introduced; in 1987, Fudge covered Oreos is introduced; in 1991,HalloweenOreos and Mini Oreos introduced; in 1995, Christmas Oreos is introduced; in summer 2011, Triple Double Oreo is introduced in America; in February 2013, Mega Stuff Oreo is introduced; and the newest in 2015, Oreo Thins is introduced.

\subsection{Definition Of Fame And Oreo Advertisement's Fame}

Advertisement and fame are two things which connected each other. Advertisement needs fame, and fame can be reached by using advertisement. Thus, both definitions of fame and advertisement are illuminated. According to Keiko Tanaka (1994), the goal of advertiser in creating an advertisement is to change consumers' thinking from inattention and uninteresting about the sell product and make them buying the sell product. Fame is a condition of someone or something when she/he/it being known well or talked about by many people, which relates to the account and global or notable achievement. It is a usual to some psychologists such as Evans, Wilson, Giles, Young, and Pinsky examine phenomena of celebrities through their psychology of famous. Otherwise, in examining a fame of an Oreo through its' advertisement is quite different.

Oreo is well known worldwide. It thanks to the advertisement produced by the advertiser. Oreo ads have already produced in many forms and many verses. 
Customers may find the Oreo advertisement in newspaper, listen through radio, and watch in television or YouTube. The main supporting factors which help Oreo growing are the brand's awardwinning advertising and best-in-class consumer promotions. The Oreo advertisement is engaged consumers to its essence by creating connections through the classic Oreo and milk ritual that brings people together in moments of childlike delight. Whether it is twisting, licking, dunking, or a combination of all three, the Oreo advertisement offers everyday moments of connection that other snack brands cannot match or unsuccessful yet.

\subsection{The Brief Summary of the Oreo Advertisement Video}

The original version of the song for the Oreo advertisement has been available 3 years ago by Owl City (Adam Young as a singer), one of popular bands in America. The fascinating side which can be found in the song is it is chanted in each country in the world using different language. Therefore, the song can be watched in different version of language according to the country belongs to. By this way, the company through the advertisement increases costumers' attention and willingness in buying Oreo, a worldwide favorite cookie.

Briefly, the song of Oreo 'Wonderfilled"'is divided into four stanzas. The first stanza tells about a relation between big bad wolf and pigs; second stanza tells the vampire and the girl relationship; third stanza tells about the great white sharks, baby seals, and giant squid relation as the animals in the sea, and the last stanza tells about somebody else who 'I' does not recognize. All the parts of the story are always arisen with the Oreo given by the first subject (I) in the clause wonder if I give an Oreo.
Besides,the lyric also indicates the interchanges from bad to good ones. For instance, in the first paragraph the big bad wolf helps the pigs to decorate the deck after eating Oreo instead of killing them previously. Also, 'I' as the main character in the song acts as a happiness spreader who wants all of the other characters in the song sharing the happiness (Oreo) to everyone; even they do not recognize the persons or animals.

As attractive as other advertisement, Oreo's advertisement uses some specific colors which have symbolic meanings. Black and white, as the original colors of Oreo, which are shown in the beginning part of the video, show the comparison between goodness and badness (see appendix: picture 1). Moreover, the shifted color done by vampire (see appendix: picture $2 \& 3$ ) indicate transformation from bad into good which can be found after eating Oreo. Picture 8 \& 9 (see appendix) shows wolf's nice attitude by helping the pigs to decorate the deck them build. Overall, the customs of lyrics, colors, and images used in the advertisement have given a positive point of view of Oreo.

\section{THE SONG LYRIC OF OREO WONDERFILLED BY OWL CITY (ORIGINAL ANALYSIS \\ VERSION)}

The song lyric of Oreo "Wonderfilled" is analyzed throughout the three dimension and seven building tasks. The three dimension consists of description, interpretation, and explanation while the seven building tasks consists of significance, practices, relationships, identities, politics, connections, and sign system of language.

\subsection{The Fame of Oreo Advertisement in Attracting the Costumers through Fairclough three-dimension}

Beyond Linguistika Vol.1, Nomor 1 beyondlinguistika@ubl.ac.id 
Fairclough (1995) stated that he refers the three-dimension into the text,discourse practice, and sociocultural practice. The analysis of discourse practice involves attention to processes of text production, distribution and consumption. He also implies that analysis of text should not be artificially isolated from analysis of institutional and discourse practices within which texts are embedded. The interpretation of the text is a dialectical process resulting from the interface of the variable interpretative resources people bring to bear on the text and properties of the text itself. Textual analysis presupposes a theory of language and a grammatical theory, which critical discourse analysis has to have. It is functional theory of how language is structured to its primary social functions. Therefore, textual analysis is important since it deals with critics (Brunsdon, 1990). Figure shown below is the diagrammatic representation of threedimension approach. It demonstrates how the three-dimension are interrelated each other.

Figure1. Dimension of discourse analysis (Fairclough, 1995)

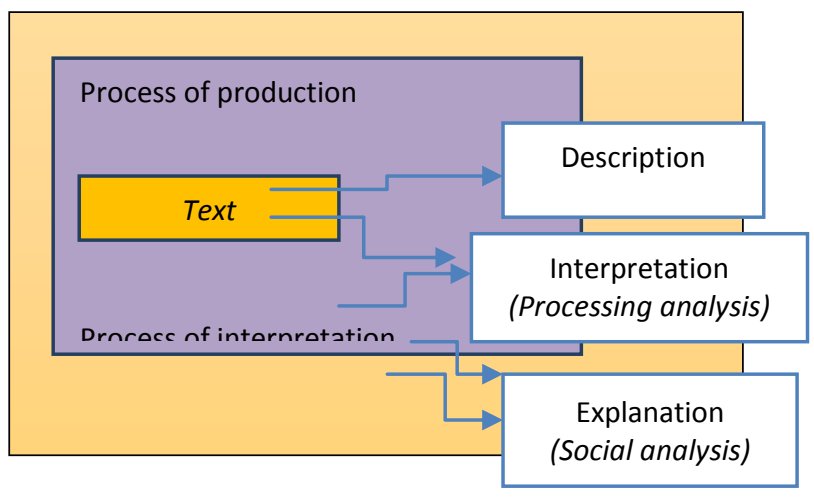

The methods of the three-dimension are description to interpretation to explanation (Fairclough, 1989, p. 26). Discourse, and any specific instance of discursive practice, is seen as simultaneously as (i) a language text, both spoken and written, (ii) discursive practice (the production and interpretation of the text), and (iii) sociocultural practice (Fairclough, 1995, p. 97). During the description phase, the focus is on textuallinguistic features of the evidence presented in the song lyric of Oreo. The researchers actively analyze the textuallinguistic features. In the interpretation phase, the researchers interpret the understanding of discourse on the basis of the relationship between the discursive processes and the text. In the last phase explanation, the researchers explain the relationship between the discursive and social processes.

\subsubsection{Description}

"Wonder if I gave an Oreo to the Big Bad Wolf,

How would the story go?

Would he still go huff and puff

Or would he bring those pigs cool stuff

To decorate the deck he helped them build?

Would they not get killed?"

\section{(Paragraph 1)}

In the first line of the first paragraph, the song displays imaginary words by using the word 'wonder' to fascinate the listener. 'Wolf' is chosen because it has negative image. In addition, it uses adjective 'big bad' to stress the wickedness of the wolf. The use of interrogative sentence in the second line aims to give curious feeling to the listener. The third and fourth line shows the contradictory sentences; whether the big bad wolf becomes problem maker or helper for the pigs after eating Oreo. This song uses alliteration at the end of each line. The same pronounce of vocal /ov/ in the words Oreo and go, consonant 
pronounce labio-dental $/ \Lambda \mathrm{f} /$ at the end of three lines, such as Wolf, puff, and stuff; also /Ild/ in the words of build and killed, give a nice harmony to the song.

"Wonder if I gave an Oreo

to a vampire in a creepy show,

Would he not act so undead?

Would he thirst for milk instead?

I've just got this feeling that it might work out all right".

\section{(Paragraph 2)}

In the next paragraph, the imaginary words of 'wonder' are still used. It has the similar organization with the previous paragraph. The song adopts 'vampire' as a bad one. The song writer uses 'milk' instead of 'blood'-which vampire supposed to drink-because milk is a mate for Oreo. The practice of acting undead is considered as negative side, while drinking milk is considered as positive side. The synchronization of this paragraph is shown by alliteration of /ov/ which can be found inOreo and show, and /ed/ in the words of undead, instead, and /art/ in the words of might and all right.

"Cause cream does wondrous things

Inside a chocolate sandwich dream".

\section{(Paragraph 3)}

In this paragraph, it consists of the meaning of Oreo. Oreo is a small thing which can change everything. It is illustrated by a cream inside a chocolate sandwich. The evidence of alliteration is illustrated by the use of consonant nasal /ri:m/ in the words cream and dream, fricative-alveolar /oz/ of words does and wondrous, and stop-alveolar /ard/ in words inside and chocolate.

"If I gave 'em to great white sharks, Would they share 'em with baby seals?

Would they call up a giant squid for a friendly meal?

Wonder if I gave an Oreo..."

\section{(Paragraph 4)}

In this paragraph, it shows the similar arrangement with the second and the first paragraph. The subjects used are the animals in the sea. They are sharks, seals, and squid. The words used are mostly adjective, for instance great, white, giant, and friendly. The use of words friendly meal gives the attention that Oreo is pleasant for anything, which meal refers to Oreo. The evidence of the alliteration can be found in consonant lateral /rəl/ of the words meal and seal.

"Wonder if I gave an Oreo... to somebody out there Who I didn't know.

Would they laugh after I'm gone?

Would they pass that wonderon?

I wonder how it changes

Your point of view

If I give one to you"

\section{(Paragraph 5)}

In the last paragraph, it gives the conclusion of the whole story of Oreo. In the fourth line, it tells that 'I' as the giver is leaving the two people. It is indicated by the preposition 'after'. The alliteration are shown by vowel /əv/ in words Oreo,know. Besides, words goneand on, after and wonder, view and you, if and give have the same alliteration.

In the sixth and seventh line, the song writer let the listener interpret the meaning by themselves. It is indicated by the sentences "I wonder how it changes your point of view, if I give one to you". One refers to Oreo. After discussing the description in the text transcribed, the researchers then interpret the text and its interaction.

\subsubsection{Interpretation}

Based on the brief summary of the advertisement, there are some characters in

Beyond Linguistika Vol.1, Nomor 1 beyondlinguistika@ubl.ac.id 
the advertisement. They are 'I' as the protagonist, and big bad wolf, a vampire, a great white shark, three baby seals, and a giant squid as the antagonist's characters. The main character in this advertisement is 'I', and others are the minor characters. After analyzing the lyric transcription, social discourse among 'I' and other characters is founded in this ad.

Referring to the interpretation of Fairclough, researchers interpret the encounter of the participants and the discourse situation. Researchers have provided the interpretation of the lyric.

In the first stanza, 'I' start the discourse by giving an Oreo cookie to a big bad wolf and wonder to what happened after the wolf eat the Oreo cookie. There are three responses from the big bad wolf. The first is the big bad wolf blue face turn into white face as the symbol that the bad attitudes of the wolf already gone. The second is the wolf become friend with three pigs which his victims before he eat Oreo cookie. The third is he helps the pig decorate the deck build by the pigs and plays with them.

In this event, ' $\mathrm{I}$ ' is acting as the main character who wonders about sharing an Oreo cookie. 'I' brings the Oreo cookie and shares to other which is in this stanza the other is the bad big wolf. 'I's wonders can be seen from all the lines in first stanza. Here, 'I' shows himself as the company who promotes its product (Oreo) and symbolized it as a goodness and happiness spreaders. By doing this, company consciously put its position as the controller that only by it the wild wolf can behave nicely and friendly. The situation picture in the first stanza also occurs in the rest stanzas. 'I' always acts as the main character.

Based on the interpretation phase, the explanation of this social discourse is explained. Referring to Talbot, music involves language, which a language implicitly bring meaning, which relates to social, culture and identity. The ideologies of the Oreo Wonderfilled song explained below.

\subsubsection{Explanation}

In the case of lyric in the Oreo ad, 'I' expresses his wonder about sharing a symbol of happiness and goodness to others (wolf, pig, shark, seal, squid, vampire, and somebody). This shows that 'I' sees the others have problems that need to be solved. The others are sad and have bad attitudes. Thus, they need 'I' as the savior who bring Oreo (the symbol of happiness and goodness) and help them to behave well. Their life will never happy without 'I' and Oreo helping.

\subsection{The Analysis of "Oreo Wonderfilled" Lyric using Seven Building Tasks}

According to Gee (2011), different linguistic approaches to discourse analysis are used to different theories of grammar and take different views about how to talk about meaning. The approaches are integration of saying (significance), doing (action), being (identity), relationships, politics, connections, and grammar as a set of tools to bring about this integration.

\subsubsection{Significance}

Significance is the signals that the speaker takes the variation according to the text to be significant by the use of some adverbs or stress words which can be markers of attitude or feeling. It uses the words to create a clear stress on the effect of tiny white cream "cream does wondrous things". It can be seen obviously that the very little thing can convey a big change. It evidences by a cream which has significant influence to the ones who have negative images like big bad wolf,

Beyond Linguistika Vol.1, Nomor 1 beyondlinguistika@ubl.ac.id 
vampire, great white sharks, and somebody out there (who described using long black coat).

\subsubsection{Practice}

There are several activities done by the practitioners of the song. They can be indicated by the use of verbs. Below is the list of verbs that specify the activities.

Table 1.The list of verbs that specify the activities.

\begin{tabular}{|c|c|}
\hline $\begin{array}{l}\text { Wonder (as the } \\
\text { beginning of each } \\
\text { paragraph) }\end{array}$ & Thirst (p.2) \\
\hline $\begin{array}{l}\text { Gave (as the } \\
\text { beginning of each } \\
\text { paragraph) }\end{array}$ & Work out (p.2) \\
\hline Go (p.l) & $\begin{array}{l}\text { Does (p.3 after } \\
\text { interlude) }\end{array}$ \\
\hline Bring (p.1) & Share (p.4) \\
\hline $\operatorname{Help}(p .1)$ & Call up (p.4) \\
\hline Build (p.1) & Laugh (p.5) \\
\hline Decorate (p.1) & $\operatorname{Pass}(p .5)$ \\
\hline Act (p.2) & Give (p.5) \\
\hline
\end{tabular}

The first until the last paragraph want to express the readers' imagination of Oreo's role, whether it would be bad or good. In the first paragraph, it tells about the attitude done by big bad wolf after given an Oreo cookie. We wonder whether he would still act as usual, huffing and puffing, or the contrary, he would help to bring the cool stuffs for the pigs and helm them (see appendix picture 4-9). The second paragraph, the role of Oreo has been completed to a vampire (see appendix picture 10-16). The next paragraph shows and stress that only a tiny thing can change anything (see appendix picture 17 and 18). The fourth paragraph specifies the sweet act of great white sharks. They would share Oreos to baby seals and call up giant squid for friendly meal (see appendix picture 19-22). The last paragraph (see appendix picture 28-
33) wants to give conclusion of all practices have pointed at one thing, that Oreo is needed can ring happiness, respect, joy, kindness, compassion, and human dignity to all.

\subsubsection{Identity}

The use of "wonder" is identified as the word mostly-used in the song. Wonder which means asking a question or express a wish to know about something, shows the identities of giving an Oreo cookie to others, whether it is going to be good or bad. Besides, the use of word "wonderfilled" can raise a positive perspective. It derives from word "wonder" (the acronym of wonderful) and "-filled" (a suffix used at the back of a word). Therefore, the word "wonderfilled" has a meaning of "full of stated thing, which is wonderful". It can be said that Oreo has full of wonderful things which is represented by a sandwich of white cream filled inside two black cookies.

\subsubsection{Politics}

The implication for the distribution of social goods that politics of Oreo have is not clearly seen. In the advertisement, the Oreo does not compare to another product. It gives a smooth commercial to the people. The way of Oreo's advertisement has implied the reader to be well-communicated. Oreo which now belongs to the Craft Company has contributed to the brand meanings and perceptions to profitability which has valued over $\$ 70$ billion. The power of symbolic representation to capture the hearts and minds of consumers is by means of visual, audio, and verbal signs.

\subsubsection{Connections}

The advertisement uses different role model as the subjects. They are animals, such as wolf, pigs, shark, seals, squid; human being; and even vampire. Then, 
Oreo acts as connector of badness and goodness characteristics of those characters. These connections can be perceived in the relevant pictures of picture 6 and 7, picture 13 and 14, picture 31 and 32 (see appendix). Oreo plays as positive connector which interchanges the characteristics of those characters from bad toward good characteristics. Moreover, it also implies the harmony between them. The aim of the harmony is showing the unity of altogether.

\subsubsection{Sign System and Knowledge}

Sign system is closely related with semiotics. Semiotics can be defined as the field, multidisciplinary in coverage and international in scope, devoted to the study of the innate capacity of humans to produce and understand sign (Albert, 1991). The semiotics approach has yielded outstanding results, proving itself to be mainly effective in the uncovering of the multiplicity of meanings within - and beyond - the text. When applied to opening paragraphs, the method has also provided a means of access to difficult and challenging works. The intention of the approach is not to be prescriptive. Semiotic analysis is an open-ended and flexible approach. It can be adopted to meet specific requirements (Martin \&Ringham). In this paper, the researchers discuss the importance of the semiotic or symbolic dimension of brands for building awareness, positive associations, and social life.

Table 2.The Semiotic Dimensions of the Brands (Oswald, 2012).

\begin{tabular}{|c|c|c|}
\hline $\begin{array}{c}\text { Material } \\
\text { performative }\end{array}$ & Conventional & Contextual \\
\hline $\begin{array}{l}\text { Words, images, } \\
\text { inter- } \\
\text { subjectivity, }\end{array}$ & $\begin{array}{l}\text { Codified by } \\
\text { tradition }\end{array}$ & $\begin{array}{l}\text { Cultural } \\
\text { nuances } \\
\text { reference }\end{array}$ \\
\hline
\end{tabular}

or rules. Logos,

packages,

advertisement.

Brands are multi-dimensional sign systems that can be analyzed in terms of their material, conventional, contextual, and performative structures. In order to be owned, perceived, or available for analysis, sign systems is considered have to be available to the senses and material dimension. For instance, in the case of visual attractiveness, the use of colors, gestures, beauty, are required to have a good look. Oreo advertisement has eyecatching with the use of fully-colored pictures (see appendix picture 1-37). Furthermore, the effect of $2 D$ animation format as the result of semi-motion graphic in the advertisement gives big influence for many people who watch it.

Besides, in the case of audio attractiveness, easy-listening voice and easy-remembered song are needed. This advertisement uses electro-pop genre music with thick auto-tune in the vocal give more ear-catchy for the listener. Both audio and visual effect which is served by this advertisement points that Oreo has a high quality of making advertisement. The company knows well how to promote their product by looking at the object of the market.

Sign systems is deliberated has to be codified. Oreo "wonderfilled" has already taken those important points. Next sign systems form social discourses whose meaning is modified by the communication context. Finally, sign systems are performative in as much as they engage two or more interlocutors (the speaker and receivers; the marketer and consumer) in a communication event. All these dimensions are at play in brand discourse, where they contribute to brand recognition emotional association's 
cultural relevance and the relationship to consumers (Oswald, 2012).

\section{CONCLUSION}

Oreo advertisement as one of food advertisement is success in achieving consumers' attention which effect to its purchasing level of the Oreo cookie. In the social discourse, Oreo ad is success in spreading the way of eat Oreo cookie to the consumers. Also, Oreo cookie becomes one of the daily snacks for the costumers. Thus, the company success in sending the message that Oreo is a symbol of goodness and happiness which may help people who unhappy and have bad attitude to behave good and nice. The use of word "wonderfilled" can raise a positive perspective. It derives from word "wonder" (the acronym of wonderful) and "-filled" (a suffix used at the back of a word). Therefore, the word "wonderfilled" has a meaning of "full of stated thing, which is wonderful". It can be said that Oreo has full of wonderful things which is represented by a sandwich of white cream filled inside two black cookies.

Since language carries meaning, the language used in Oreo advertisement has relation to power. Thus, the advertisement of Oreo does not only attract consumer but also shape the costumers' mind through the language used. The power of symbolic representation to capture the hearts and minds of consumers is by means of visual, audio, and verbal signs, which is analyzed using semiotics feature.

\section{REFERENCES}

Albert, T. \& Sebeok.1991. A Sign is Just a Sign Advances in Semiotics.US: Indiana University Press.
Brunsdon, Charlotte. 1990. Problems with Quality. Screen Volume 31 no.1-67 page 3 .

Dijk, T. A. V. 1988. Critical Discourse Analysis.Retrievedfromhttp://www.disc ourses.org/OldArticles/Critical\%20disc ourse $\% 20$ analysis.pdf on Thursday, December $10^{\text {th }} 2015$.

Gee, J. P. 2011. An Introduction to Discourse Analysis. New York: Taylor and Francis Routledge.

Fairclough, Norman. 1989. Language and Power. US: Longman Inc.

Fairclough, Norman. 1995. Media Discourse. London: Bloomsbury Academic.

Maltby, John, Day, Liz, at all. Implicit Theories of a Desire for Fame.UK: University of Leicester.

Martin, B. \&Ring ham, F. 2000. Dictionary of Semantics. London and New York: CASSELL.

Oswald, Laura R. 2012. Marketing Semiotics Signs, Strategies, and Brand Value.In Swaroop Simha.Role of Semiotics in Strategic Brand Management with Reference to an Omani Bank. Barcelona: Annual Spain Business Research Conference 2015

Rosenberg, Jennifer.2016. History of the Oreo Cookie.Retrieved from http://history1900s.about.com/od/1910s laloreohistory.htmon Monday, 4th February.

Tanaka, Keiko. 1994. Advertising Language: A Pragmatic Approach to Advertisements in Britain and Japan. New York: Taylor and Francis Routledge. 


\section{Appendix}

The List of Pictures (Captured from the Advertisement Video).

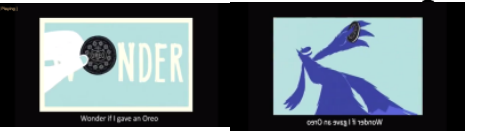

Picture 1. Picture 2.

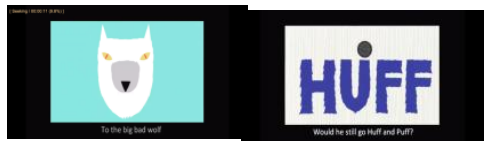

Picture 3. $\quad$ Picture 4.

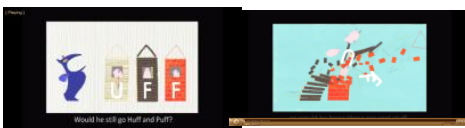

Picture 5. $\quad$ Picture 6.

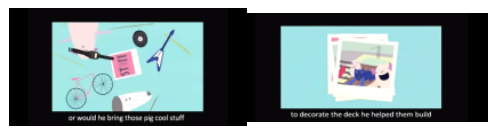

Picture $7 . \quad$ Picture 8.

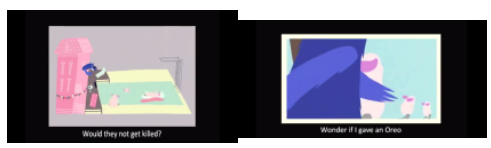

Picture 9. $\quad$ Picture 10.
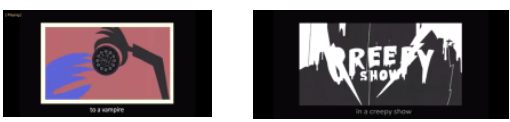

Picture 10. Picture 11.
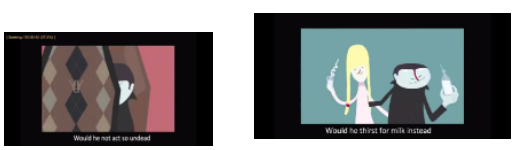

Picture 12. Picture 13.

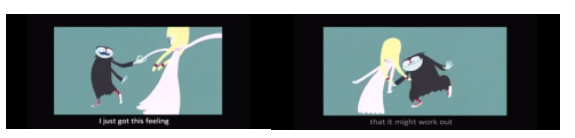

Picture14. Picture15.

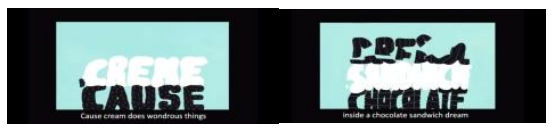

Picture 16. Picture 17

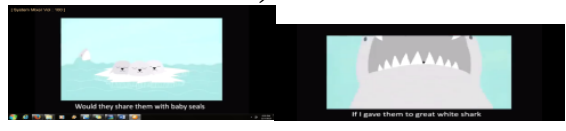

Picture 18. Picture 19.

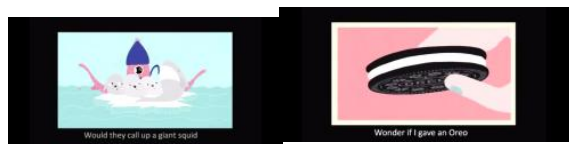

Picture20. Picture 21.

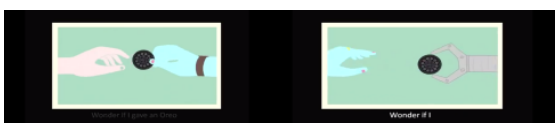

Picture 22. Picture 23.

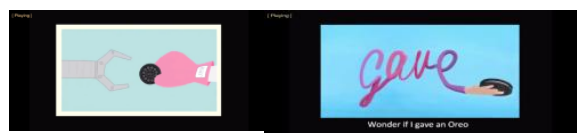

Picture 24. Picture 25.

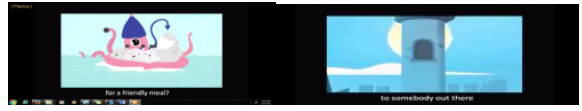

Picture 26. Picture 27.

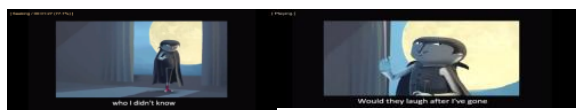

Picture 28. Picture 29.

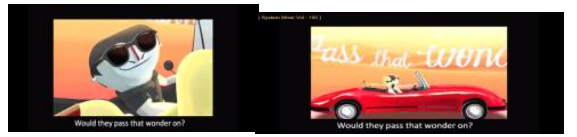

Picture 30. Picture 31.

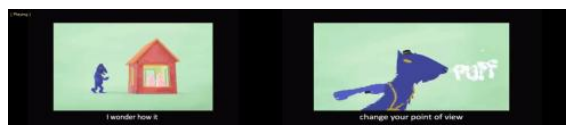

Picture 32. Picture 33.

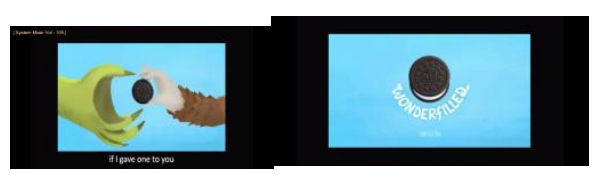

Picture 34. Picture 35.

Beyond Linguistika

Vol.1, Nomor 1 beyondlinguistika@ubl.ac.id 